\title{
Historical earthquake investigations in Greece
}

\author{
Vicki Kouskouna and Kostas Makropoulos \\ Department of Geophysics and Geothermics, \\ National and Kapodistrian University of Athens, Greece
}

\begin{abstract}
The active tectonics of the area of Greece and its seismic activity have always been present in the country's history. Many researchers, tempted to work on Greek historical earthquakes, have realized that this is a task not easily fulfilled. The existing catalogues of strong historical earthquakes are useful tools to perform general SHA studies. However, a variety of supporting datasets, non-uniformly distributed in space and time, need to be further investigated. In the present paper, a review of historical earthquake studies in Greece is attempted. The seismic history of the country is divided into four main periods. In each one of them, characteristic examples, studies and approaches are presented.
\end{abstract}

Key words historical earthquakes - earthquake catalogues - Greece

\section{Introduction}

In general, earthquakes in Greece are strongly related to everyday life, within the country's course in history. The strong earthquakes that have occurred in this, relatively limited, area of the eastern Mediterranean have affected the history, tradition, religion, arts, building habits, political, social and economic status for a very long time. Early scientific approaches to this natural phenomenon were made by philosophers in antiquity. Even recently, the Kocaeli (1999 Turkey) and Athens (1999 Greece) earthquakes gave impetus to the introduction of the new term «earthquake diplomacy», which in turn has been a breakthrough for a strong basis in bilateral collaboration.

Mailing address: Dr. Vicki Kouskouna, Department of Geophysics and Geothermics, National and Kapodistrian University of Athens, Panepistimiopolis, 15784 Athens, Greece; e-mail: vkouskouna@geol.uoa.gr
The high seismic activity of the country is due to the fact that it is located at the boundary of the Africa-Eurasia convergence. Within this framework, the Anatolian plate rotates counterclockwise (fig. 1). From the west, the Adria microplate rotates counterclockwise. As a consequence, the Aegean microplate moves fast towards SW. The external Aegean area is subject to a general compressional stress field and the inner Aegean area experiences a general extensional stress field.

Greece often hosts large magnitude earthquakes, whilst a moderate or small magnitude earthquake is felt every 2-3 days on average (fig. 2). Although the majority of these earthquakes are shallow, a few cases have been recorded as «devastating» for the human environment or for life loss (e.g., the 1881 Chios, 1953 Cefallonia, 1999 Athens earthquakes). No historical information is provided for extensive migration of populations and obliteration of civilizations in Greece due to earthquakes. This, however, can be due to the fact that the earthquakes which usually cause damage in Greece are relatively small. Major shallow earthquakes $(M>8$, return period of about 1000 years), which can cause such extensive destructions occur rarely. 


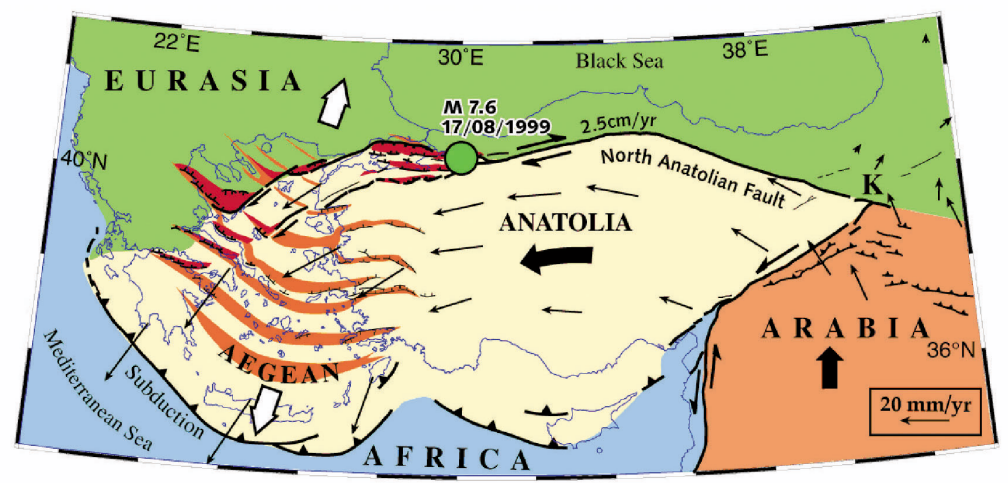

Fig. 1. Active tectonics in the Aegean and surrounding area (Armijo et al., 1999).

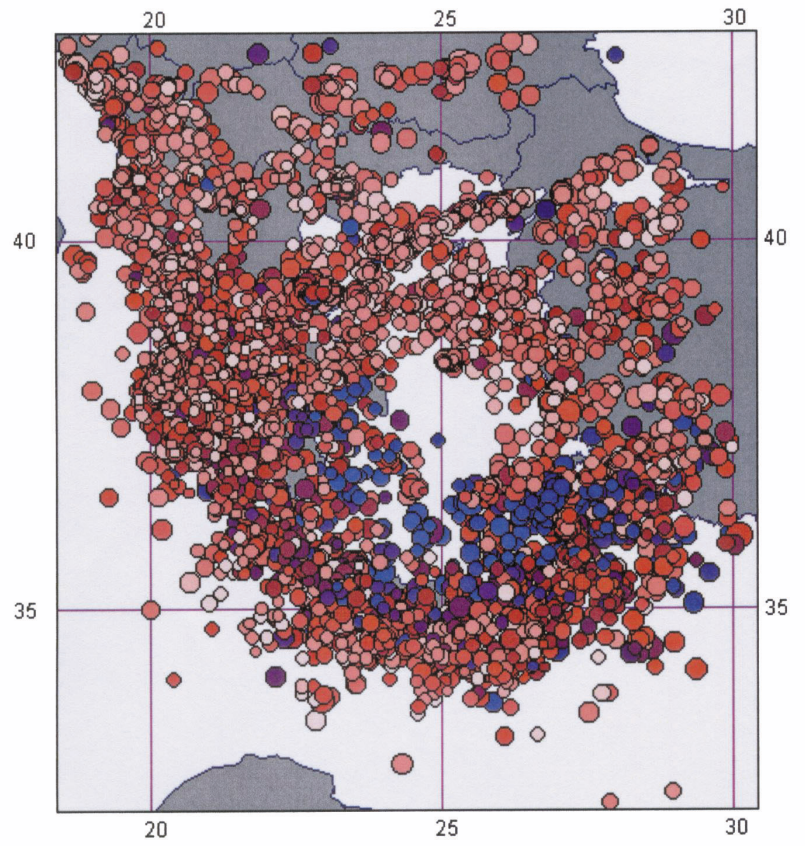

Fig. 2. 20th century earthquake epicentres with $M \geq 4$ distribution in the broader area of Greece (Makropoulos et al., 2001). Red and blue colour ranges represent shallow and intermediate depth earthquakes, respectively.

\section{History of earthquake observations in Greece}

The observation and description of the effects of earthquakes in Greece which commenced in early antiquity, i.e. after 6th century B.C., can be found as Greek and Latin sources, both texts and epigraphic material. In these texts, the experience of earthquakes was such, that it triggered the recording of their effects. Until the middle 19th 
century this work was carried out by non-specialists (philosophers, historians, travellers, etc.), who were mainly interested in (or impressed by) earthquake effects, usually without giving any significant information on minor events or earthquake sequences. Within the context of a wider European consideration of earthquakes with respect to major historical or political events, Greece has reported a considerable number of destructive earthquakes (Albini and Stucchi, 1997).

After 1850, the cumulative number of known earthquakes with time increased dramatically, meaning that seismology was finally established as a science. The period of Greek historical earthquakes ends in 1898 (installation of the first seismograph of «Agamenone» type in the National Observatory of Athens) or 1911 (installation of the seismometer of «Mainka» type). In fact, this period is practically extended up to the first decades of the 20th century. In any case, for many researchers, the 1894 Atalanti earthquakes are the last destructive historical events in Greece.

\section{Historical earthquake investigations in Greece}

Julius Schmidt (1825-1884), the first director of the National Observatory of Athens (18581884), collected information on past Greek earthquakes and listed them in chronological order (Schmidt, 1879). He was the first to organize a network for macroseismic observations. D. Barbiani (1788-1866) and his grandson B. Barbiani collected rich observational material on the earthquakes of Zakynthos, Ionian islands (Barbiani and Barbiani, 1864). Von Hoff (1840, 1841), Perrey (1848) and Mallet (1853-1855) also published catalogues of earthquakes in which the Greek events were included. In many cases, interaction between these catalogues is observed, since they quote each other as references. In the early 20 th century Sieberg (1932a) included Greek historical earthquakes in his «Erdbebengeographie». Such descriptive catalogues are known as classical compilations.

On a local basis, earthquakes attracted the interest of historians who published earthquake histories (e.g., Stamatelos, 1870)
Around the mid-20th century, Galanopoulos published a number of studies in which he introduced parameters for the listed historical earthquakes. In his first attempts he introduced the assessed intensity (e.g., Galanopoulos 1953) and later on he compiled the first parametric catalogues of damaging historical earthquakes in Greece (Galanopoulos 1960, 1961) in which, apart from the main parameters (date, time, epicentral coordinates, two depth ranges and maximum intensity) additional information of interest is provided, as well as references for each event. These catalogues list a total number of 140 events with $I_{0} \geq$ VII for the period 2000 B.C. -1799 and 151 events with $I_{0} \geq$ VI for the period 1800-1899. For a large number of events, Sieberg $(1932 a, b)$ was his main reference.

Based on these catalogues for the area of Greece, together with additional sources and events, Kárník (1971) included Greek historical earthquakes in his parametric catalogue of European earthquakes. A few years later, Shebalin et al. (1974) compiled the catalogue of earthquakes of the Balkan region and the atlas of isoseismal maps (Shebalin, 1974). The latter included a small number of historical earthquakes. The latest published catalogues of historical earthquakes were presented by Papazachos and Papazachou (1989, 1997, 2003).

In parallel with catalogues, important studies of specific seismological interest appeared in the first half of the 1900s. The collections of memory notes from monasteries around Greece, in which earthquake occurrence and effects are mentioned, providing valuable information for certain periods with practically non-existent state archive material. Amongst others, Lambros (1910) and Maravelakis (1938) and Schreiner (1975) are the best known examples.

The evaluation of the above mentioned studies strongly depends on their supporting data sets. For the period before 1500 historical texts should be studied in relation to major archaeological studies. For the period after 1500 the memory notes collections and the earthquake histories, relying mostly on eye-witness descriptions, should be considered of greater value.

In the last decades, the interest in historical earthquakes in Greece was revived, due to the fact that seismic hazard assessment studies based on 
20th century earthquakes proved to be incomplete for events with long recurrence periods, and especially for those of moderate magnitude. To this aim, unpublished sources were revealed and investigated and a close collaboration between seismologists and historians was established (e.g., Albini, 1991; Ambraseys and Finkel, 1992; Ambraseys and Jackson, 1997; etc.). In these studies material from archives outside the Greek territory (Venetian, Ottoman) were exploited.

Such efforts proved the necessity of a more thorough and systematic search for unpublished material. Many events had to be cross-checked, their effects distribution was incomplete, some were over- or underestimated, the date and time of their occurrence needed to be clarified. The sources, on which seismological interpretation was based, varied in quality and quantity. These problems were common throughout Europe, for different reasons in each country (Stucchi et al., 1990).

The RHISE project proved to be a perfect opportunity for the collaboration between seismologists and historians from neighbouring countries, exchange of data and systematic study of sources reporting historical earthquakes (e.g., Kouskouna et al., 1993, Ambraseys and Finkel, 1993).

Having established a «common language» on the study of historical earthquakes in Europe, in the BEECD project that followed soon after, a European catalogue of historical earthquakes was compiled, in which the existing paremetric earthquake catalogues were evaluated and upgraded according to standard procedures. In many cases, recent studies on historical earthquake investigations improved the quality of the existing entries (Albini and Stucchi, 1997) and increased the number of earthquakes.

The long seismic history of Greece shows a varied picture of seismic activity in time. Taking into account the variety of historical events occurring throughout the centuries, the existence of revealed sources is unequal. The question raised is if there is a lack of sources or a lack of earthquakes. In certain flourishing areas, socially and economically, ample sources are available regarding their seismic activity (e.g., Ionian, Eastern Aegean islands), in contrast to poor information from underdeveloped areas (e.g., central Greece). In addition, recent seismic activity in areas of poor or no seismic history (e.g., 1995 Kozani, 1999 Athens) suggest the need for further investigation towards revealing new or exploiting existing material. Thus, in recent years, catalogues have been enriched and updated (e.g., Papazachos and Papazachou, 2003) and studies on specific areas, events, etc. have been published (e.g., Kouskouna, 2001; Taxeidis, 2003).

\section{Periods of historical earthquakes}

For the study of the historical earthquakes in Greece, a large variety of sources can be located, evaluated and exploited. They represent a context within which significant historical events have interacted through a period of about 2500 years. Although making a categorization of the sources as a whole for such an extended period might be considered a simplification, they can be distinguished as follows:

- unpublished manuscripts;

- archive material;

- ancient and Byzantine writers;

- press;

- published sources;

- historical textbooks;

- maps and geographic guides;

- seismological compilations;

- earthquake catalogues.

The completeness of the above-mentioned source material is not uniform in time. For the period before 1500 it is almost certain that most of the existing quotations on significant earthquakes have been exploited.

Any future tracking of new historical sources should, most probably, refer to the end of the 16th century. After 1500 the number of available sources increases progressively with time. In view of the type and the contents of the available sources the period of Greek historical earthquakes can be divided into four main sub-periods.

\subsection{Up to 1000 A.D.}

The study of earthquakes in this period is based on the preserved ancient and Byzantine texts, most of which can be easily accessed, and 


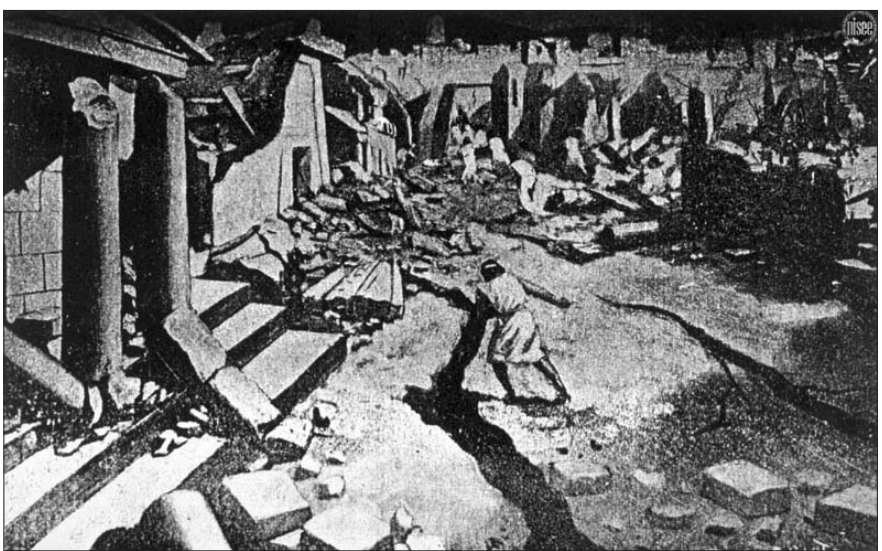

Fig. 3. City of Sparta destroyed by the earthquake of 464 B.C., according to the [painting or description] by Egisto (book illustration, Images of Historical Earthquakes, The Jan T. Kozak Collection, on line: $\mathrm{http} / / /$ nisee.berkeley.edu/kozak/). This earthquake was one of the most destructive in Antiquity. According to several historians (e.g., Plutarch and Strabo) the town was destroyed from its foundations. More than 20000 people were killed and only five houses were left intact. In an arcade where young Spartans were exercising, the gymnasium collapsed and they were all killed. Their tomb was called «seismatias», after the earthquake (Dermitzakis et al., 1997).

on the epigraphic material revealed by the archaeological excavations. However, specific historical and archaeological research is necessary for the identification of certain localities that have experienced strong earthquakes, but mainly for the dating of the events, which is a rather difficult task: the earthquakes are reported in relation to important events described by historians.

The ancient Greek philosophers attempted several explanations on the earthquake phenomenon: Anaximenis of Miletos (585-528 B.C.) attributed the earthquake occurrence to temperature changes in the earth's interior.

Aristotle (384-322 B.C.) provided an integrated explanation, based on the interpretations of previous philosophers and his own observations: the earthquakes are due to interaction of air currents on the earth's surface and in its interior.

In some cases the earthquake occurrence is interpreted as the consequence of the wrath of gods, e.g., for war expeditions. The traveller and historian Pausanias (2nd century A.D.) refers to the 464 B.C. Sparta earthquake (fig. 3):
«... when the Spartans killed the men who had found sanctuary in the temple of Poseidon in Tainaron, some time later a continuous and strong earthquake struck their town, so that no house in Sparta escaped destruction... The Spartans, who ignored their supplicants, met the wrath of Poseidon; the god razed the whole town to the ground...» (Dermitzakis et al., 1997).

Early attempts were made to list the earthquakes of this period (e.g., Georgiadis, 1904). Since then, modern seismological compilations, such as those of Guidoboni (1989), Guidoboni et al., (1994), Ambraseys and White (1996), etc. have systematically indexed the ancient writers and exploited the related archaeological and historical studies.

\section{2. $1000-1500$}

In this period, the Byzantine historians are the main authors of information, together with the Venetian State Archives, local archives, chronicles and marginal notes. Towards the end of this period, the ancient Greek civiliza- 


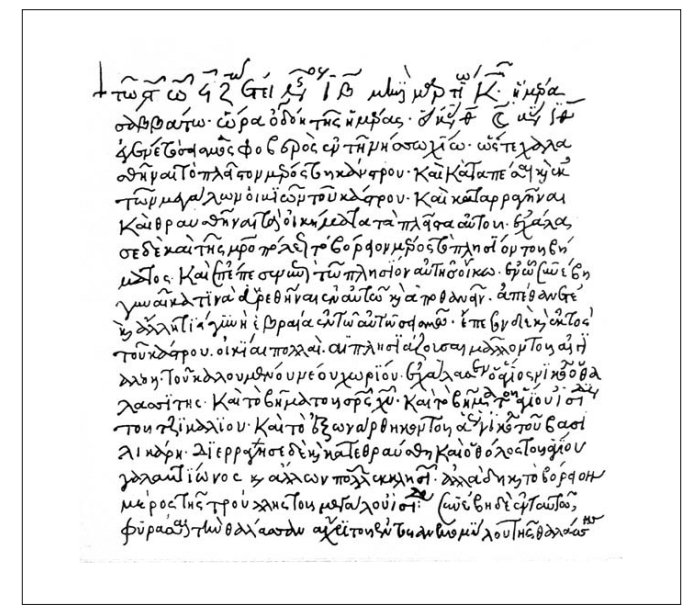

Fig. 4. A note written in Chios detailing the effects of the 1389 earthquake in the town of Chios: Code Ottobonianus Graecus n. 2381 (f. 335), Vatican library. The translation of the note into modern Greek can also be found in Taxeidis (2003).

tion, as well as the suffering, occupied Greeks, attracted travellers from western Europe visiting the country (e.g., Simopoulos, 1970). The relatively limited number of earthquakes described in this period may be due to the decline of the Byzantine empire. The historical study of Evangelatou-Notara (1993) contains a large number of events for the period 12001500 , based on the texts of contemporary historians and on short chronicles and memory notes.

Seismological compilations on earthquakes of this period exploit the above-mentioned sources and reveal new ones. For example, the picture of the 20 March 1389 Chios event is enriched by a note contemporary to the earthquake (fig. 4), which gives a detailed description of its effects on several specific churches in the town (Taxeidis, 2003).

\section{3. $1500-1800$}

The basic study for the historical earthquakes is by Ambraseys and Finkel (1995), based on several, contemporary to the events, sources and on the Ottoman archives. Additional valuable information may be derived from historical studies focusing on specific areas, diplomatic archives of western European countries, travellers' accounts and memory notes from ecclesiastical and monastery books. In the travellers' texts, the interpretation should be carried out with special care, since their accounts are not always based on eyewitness reports. Thus, in many cases the memory notes prove to be more realistic because they were written by local people who experienced the earthquake. Such a case is the Mytilini earthquake around the year 1528. It is mentioned by Benedetto Bordone (1476-1531), Italian painter and geographer, who described various islands in the eastern Aegean Sea and their history, but it is not certain whether he actually visited Mytilini and experienced the earthquake. Eventually, his description is considered to be realistic, after taking into account the 5th Code of Mytilini Parish (Taxeidis, 2003).

Detailed interpretation and search for additional sources may improve the assessment of parameters of existing earthquakes. Such is the case of the 1769 Leukada earthquake, which had originally been overestimated (Makropoulos and Kouskouna, 1994).

\section{4. $1800-1900$}

The problem of inaccessibility to the Ottoman archives in the first half of the century is still apparent (lack of sources). In general, the number of earthquakes increases considerably in the second half of the century (availability of sources). Local authorities, the press, relying on local reports and telegrams, and local observers appointed by the National Observatory, report on earthquake activity.

In the late 19th century, the most fatal earthquake in the seismic history of Greece struck SE Chios island on 3 April 1881 (M6.6). Hundreds of people were killed and the majority of houses, castles, towers and churches were completely destroyed. Several detailed reports describe in detail the mainshock and its fore- and aftershock activity (fig. 5). Detailed accounts from each village, as well as photographic ma- 

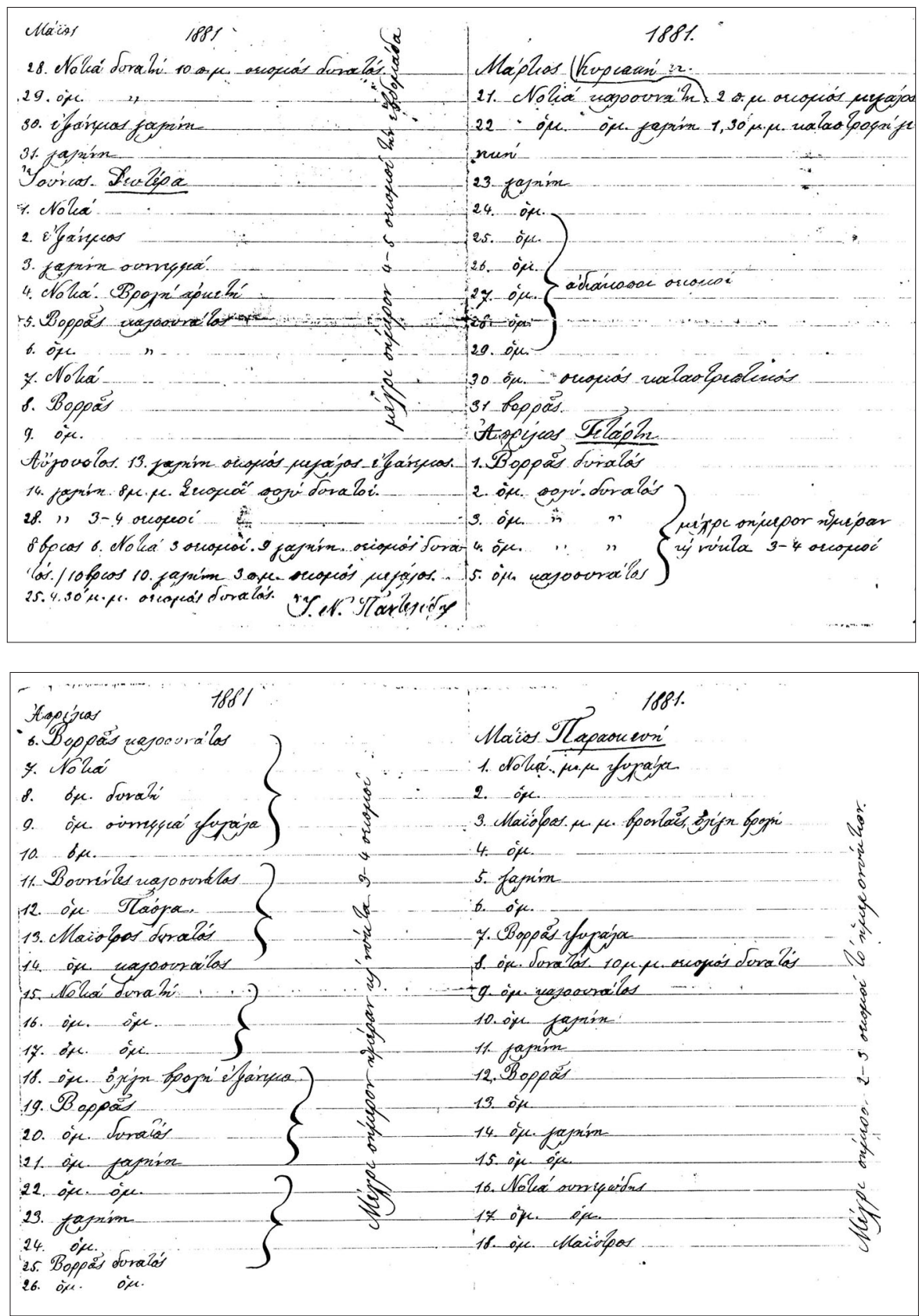

Fig. 5. Earthquake and weather report: an unpublished manuscript written by I.N. Pantelides (19th cent., further details unknown). The manuscript is kept at the Ioannis Choremis archives in Chios, Greece. It commences on Sunday, 22 March 1881 (OS-old style) and ends on 25 December 1881 (OS). The exact date and time of the mainshock of (22 March) 4 April Chios (M 6.5) earthquake and its aftershocks are listed. 


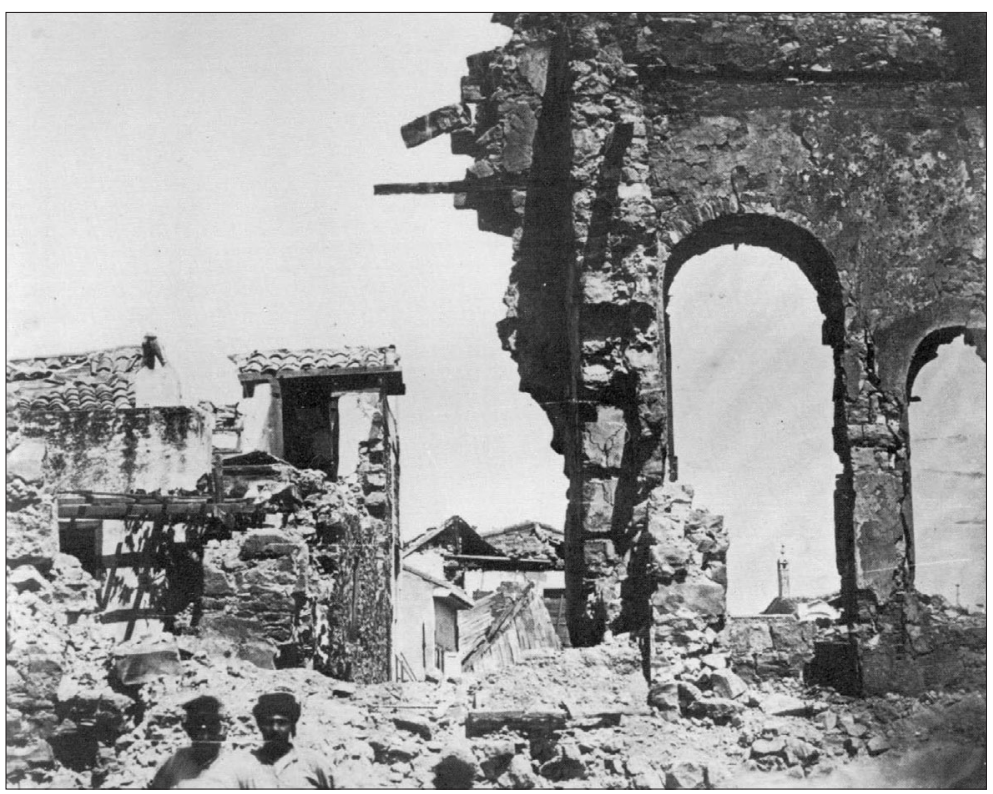

Fig. 6. Chios town: the Aplotaria commercial centre after the 1881 earthquake (Fasoulakis and Bouras, 1983).

terial allow for a complete picture of the damage distribution (fig. 6).

Depending on the available sources, smaller events from areas of moderate seismicity can also be investigated and the seismic histories of sub-areas may be completed (e.g., Kouskouna, 2001; Taxeidis, 2003). It is also noteworthy to mention that in this period, a large number of intensity datapoints for the area of Greece is available.

\section{Acknowledgements}

The authors wish to thank Ioannis Choremis for his permission to use the unpublished manuscript of the 1881 earthquake sequence listing and Alexandros Zannas for providing a copy of this manuscript.

\section{REFERENCES}

AlbinI, P. (1991): Datazione e prima stima degli effetti dei terremoti nelle Isole Ionie nell'anno 1767 da documen- ti veneziani, in Atti del Convegno GNDT, edited by $\mathrm{P}$ Albini and M.S. BARBANO, Macrosismica, Bologna, vol. 2, 111-124.

Albini, P. and M. STUCCHI (1997): A Basic European Earthquake Catalogue and a Database for the evaluation of long-term seismicity and seismic hazard (BEECD), in Seismic risk in the European Union, edited by A. GHAZI and M. YEROYANNI (Brussels-Luxembourg), vol. I, 53-77.

Ambraseys, N.N. and C.F. FinKel (1992): The seismicity of the Eastern Mediterranean region during the turn of the eighteen century, Istanbuler Mittelungen, 42, 148162.

Ambraseys, N.N. and C.F. FinKel (1993): Material for the investigation of the seismicity of the eastern Mediterranean region during the period 1690-1710, in Historical Investigation of European Earthquakes, Materials of the CEC Project: Review of Historical Seismicity in Europe, edited by M. STUCCHI (CNR, Milano), vol. 1, 173-194.

Ambraseys, N.N. and C.F. FinKEL (1995): The seismicity of Turkey and adjacent areas. A historical review, 1500-1800, EREN, 34-95-Y-70-061, pp. 240.

AMBRASEYS, N.N. and J.A. JACKSON (1997): Seismicity and strain in the gulf of Corinth (Greece) since 1964, J. Earthquake Eng., 1, 433-474.

AmBRASEYS, N.N and D.P. White (1996): Seismicity of the Eastern Mediterranean and Middle East-I, ESEE Res. Rep. No. 96-3 (Imperial College, London).

Armijo R., B. Meyer, A. Hubert and A. BArKa (1999): 
Westwards propagation of the North Anatolian Fault into the Northern Aegean: timing and kinematics, $G e$ ology, 27 (3), 267-270

BARBIANI, D.G. and B.A. BARBIANI (1864): Mémoire sur les tremblements de terre dans l'île de Zante, Mém. Acad. Sci. Dijon, 1-112.

Dermitzakis, M., K. Kouli, K. Makropoulos and V. KousKounA (1997): Historical earthquakes in ancient Greek writings: a case study of «Ellados periegesis» by Pausanias, in Archéologie et Sismicité autour d'un grand monument, le Pont du Gard, edited by J.-L. Fiches, B. Helly and A. Levret (Editions APDCA), 41-51.

Evangelatou-Notara, F. (1993): Earthquakes in Byzantium (13th-15th century), historical investigation, Parousia, 24 (special issue), pp. 184 (in Greek).

FAsOUlakis, S. and C. Bouras (1983): Photo album depicting the ruins in Chios from the 22/3 April 1881 earthquake, Yennadios Library Publ., 48 photographs.

Galanopoulos, A.G. (1953): Katalog der Erbeben in Griechenland für die Zeit von 1879 bis 1892, Ann. Géol. Pays Hellén., 5, 144-229.

Galanopoulos, A.G. (1960): A Catalogue of Shocks with $I_{o} \geq$ VI or $M \geq 5$ for the Years 1801-1958, Athens, pp. 119.

Galanopoulos, A.G. (1961): A Catalogue of Shocks with $I_{o} \geq$ VII for the years prior to 1800 , Athens, pp. 19 .

GEORGIADIS, S.A. (1904): About earthquakes and antiseismic constructions, Publ. S. Kousoulinou, Athens, pp. 306 (in Greek).

GuIDoboni, E. (1989): I Terremoti Prima del Mille in Italia e nell'Area Mediterranea (ING, Roma-SGA, Bologna), pp. 765 .

Guidoboni, E., A. Comastri and G. Traina (1994): Catalogue of the Ancient Earthquakes in the Mediterranean Area up to the 10th Century (ING, Roma-SGA, Bologna), pp. 504.

HoFf, K.E.A. VON (1840): Chronik der Erdbeben und VulcanAusbrüche, I. Theil (Justus Perthes, Gotha), pp. 470.

Hoff, K.E.A. vON (1841): Chronik der Erdbeben und VulcanAusbrüche, II. Theil (Justus Perthes, Gotha), pp. 406.

KÁRnÍK, V. (1971): Seismicity of the European area Part II, (D. Reidel Publ. Comp., Dordrecht, Holland), pp. 218.

Kouskouna, V. (2001): The (December 28th, 1891) January 9th, 1892 Larisa (central Greece) earthquake, in Proceedings of the 9th International Congress of the Geological Society of Greece, September 2001, Athens, 1425-1432 (in Greek).

Kouskouna, V., K.C. Makropoulos and K. Tsiknakis (1993): Contribution of historical information to a realistic seismicity and hazard assessment of an area. The Ionian Islands earthquakes of 1767 and 1769: historical investigation, in Historical Investigation of European Earthquakes, Materials of the CEC Project: Review of Historical Seismicity in Europe, edited by M. STUCCHI, (CNR, Milano), vol. 1, 195-206.

LAMBros, S.P. (1910): Memory notes, first collection, Neos Ellinomnimon, Athens, 7, 133-257 (in Greek).

MaKropoulos, K.C. and V. KousKouna (1994): The Ionian Islands earthquakes of 1767 and 1769: seismological aspects. Contribution of historical information to a re- alistic seismicity and hazard assessment of an area, in Historical Investigation of European Earthquakes, Materials of the CEC Project: Review of historical Seismicity in Europe, edited by P. ALBINI and A. MORONI (CNR, Milano), vol. 2, 27-36.

Makropoulos, K.C., J.K. Drakopoulos and J.B. LATOUSAKIS (1989, 2001 updated): A revised and extended catalogue for Greece since 1900, Geophys. J. Int., 98, 391-394.

Mallet, R. (1853, 1854, 1855): Catalogue of recorded earthquakes from 1606 B.C. to A.D. 1850, Brit. Ass. Rep., 1853, 1-176; 1854, 118-212; 1855, 1-326.

MaravelaKis, M.J. (1938): A Contribution to the Knowledge of the History of the Earthquakes in Greece and its Neighbouring Countries from the Memory Notes (Publ. M. Triantafyllou, Thessaloniki), vol. 13, pp. 80 (in Greek).

PAnTELides, I.N. (19th cent.): Earthquake and Weather Reports, Ioannis Choremis archives, Chios, Greece, ms.

Papazachos, B. and C. PAPAZACHOU $(1989,2003)$ : The Earthquakes of Greece (Ziti Publ., Thessaloniki), pp. 356; pp. 286 (in Greek).

PAPAZAChOS, B. and C. PAPAZACHOU (1997): The Earthquakes of Greece (Ziti Publ., Thessaloniki), pp. 304.

Perrey, A. (1848): Mémoire sur les tremblements de terre ressentis dans la péninsule Turco-Hellénique et en Syrie, T. XXIII, Publ. Academie Royale de Belgique, pp. 73.

Schmidt, J.F.J. (1879): Studien über Erdbeben, Leipzig, pp. 360.

SCHREINER, P. (1975): Die Byzantinischen Kleinchroniken, Verlag der Osterreichischen Akademie der Wissenchaftern, Wien, Teil 1, Einleitung und text, pp. 688; Teil 2, Historischer Kommentar, pp. 644; Teil 3, Teilubersetsungen, addenda et corrigenda, indices, pp. 254.

SHEBALIN, N.V. (Editor) (1974): Atlas of isoseismal maps, UNDP-UNESCO Survey of the Seismicity of the Balkan Region, Part III, Skopje, 275 maps

SHEBALIN, N.V., V. KÁRNíK and D. HADZIEVSKI (Editors) (1974): Catalogue of earthquakes of the Balkan region, UNDP-UNESCO Survey of the Seismicity of the Balkan Region, Part I and Part II, Skopje, pp. 600.

SieBERG, A. (1932a): Die Erdbeben, in Handbuch der Geophysik, edited by B. GuTENBERG (Berlin), vol. IV, 6871005 .

SIEBERG, A. (1932b): Untersuchungen über Erdbeben und Bruchschollenbau im Östlichen Mittelmeergebeit, Denkschr. Medizin.-Natürwiss. Ges., Jena, 18 (2), 161-273.

Simopoulos, K. (1970): Foreign travellers in Greece, Athens, 333-1700 (in Greek).

Stamatelos, J.N. (1870): The thirteen destructions of Leukada from 1612 up to 1869, in Efemeris ton Filomathon, 24 January 1870, Athens, 726 (in Greek).

Stucchi, M., A. Bellani and E. Chignola (1990): Behind the intensity map: assessing the quality of historical seismological information, in ESC 3rd International Workshop on Historical Earthquakes in Europe, April 4-6, 1990, Liblice (invited paper).

TAXEIDIS, K. (2003): Investigation of historical earthquakes in the East Aegean islands, Ph.D. Thesis (University of Athens), pp. 301 (in Greek). 